\title{
Московский Университет: Новая страница в его истории
}

\author{
В.С. Ржеуцкий \\ Deutsches Historisches Institut Moskau \\ rjeoutski@gmail.com
}

История Московского университета (вторая половина XVIII века - начало XIX века). Сборник документов. Т. 1 (1754-1755). Составитель, автор вступительных статей и примечаний Д.Н. Костышин. Отв. ред. Е.Е. Рычаловский. М.: Academia, 2006; Т. 2 (1756). Составитель, автор вступительных статей и примечаний Д.Н. Костышин. Отв. ред. Е.Е. Рычаловский. М.: Aсаdemia, 2011; Т. 3 (1757). Составитель, автор вступительных статей и примечаний Д.Н. Костышин. М.: Academia, 2014.

История Московского университета, публикуемая Д.Н. Костышиным, является обширным собранием документов по истории первого российского университета (если не считать таковым скромное учреждение, существовавшее до 1755 г. при Петербургской Академии наук). ${ }^{1}$ Известно, что почти весь архив университета погиб в пожаре Москвы в 1812 г. Уцелевшие документы составили так называемое "Снегиревское" собрание библиотеки Московского университета, в которое входят протоколы конференции университета, ордера кураторов, рапорты директоров, переписка канцелярии и т.д. Большинство документов из этого собрания было опубликовано Н.А. Пенчко в 1960-1963 гг. ${ }^{2}$ Долгое время это была единственная крупная публикация документов по истории университета, охватывавшая период с 1756 по 1770 и включавшая также несколько документов за 1786 г. Серия, начатая в 2006 г. Д.Н. Костышиным, на нынешний момент “покрывающая" 1754-1757 гг., по своему объему уже превзошла издание Пенчко. Изначально намереваясь издавать по тому на каждые два-три года существования университета, составитель уже со второго тома был вынужден посвящать каждому году отдельную книгу.

Т. 1, 1754-1755 гг., 471 с.: автор выявил 120 документов за 1754 г., и опубликовал из них 61; 231 документ за 1755 г., из которых 170 было им опубликовано в книге.

Т. 2, 1756 г., 376 с.: 229 выявленных документов, из них 163 опубликовано в книге.

Т. 3, 1757 г., 816 с.: 404 выявленных документа, 348 опубликованных.

Таким образом, все три тома содержат 742 документа.

\begin{tabular}{|c|c|c|}
\hline Год & Выявленных документов & Из них опубликовано в книге \\
\hline 1754 & 120 & 61 \\
\hline 1755 & 231 & 170 \\
\hline
\end{tabular}

${ }^{1}$ В первых двух томах ответственным редактором был Е.Е. Рычаловский, в т. 3 ответственного редактора больше нет.

${ }^{2}$ Документы и материалы по истории Московского университета второй половины XVIII века. Подг. к печати Н.А. Пенчко (М., 1960-1963), Т. 1-3. 


\begin{tabular}{|c|c|c|}
\hline 1756 & 229 & 163 \\
\hline 1757 & 404 & 348 \\
\hline Всего & 984 & 742 \\
\hline
\end{tabular}

Составитель также приводит список выявленных документов, которые он решил не публиковать по разным причинам. Сразу же оговоримся, что не все документы публикуются Д.Н. Костышиным впервые. Некоторые важные с его точки зрения, ранее уже публиковавшиеся документы он воспроизводит в своей истории, что делает это издание удобным для историка. Документы публикуются в хронологическом порядке с воспроизведением главных особенностей оригинала (так, пропущенные буквы воспроизводятся, но указываются в квадратных скобках). Публикация выполнена по условиям, оговоренным в первом томе этого издания и ее можно считать во многих отношениях образцовой.

Процент новых и ранее опубликованных документов не оговаривается в предисловии, но, если немного потрудиться, его можно выявить, так как все документы сопровождаются точной библиографической и архивной ссылкой. За 1754 г., т.е. год, когда происходила подготовка основания нового учебного заведения, около 97\% всех документов, приводимых Костышиным, публикуются впервые. За 1755 г., т.е. в год основания университета, таковых около $77 \%$. В то же время многие из ранее опубликованных документов были введены в оборот самим составителем, который уже много лет занимается поиском документов по истории Университета. Из других часто используемых в т. 1 изданий нужно назвать уже упомянутую публикацию Пенчко и переписку Леонарда Эйлера. ${ }^{3}$ Кроме того, публикация содержит приложения - это, как правило, документы, имеющие прямое отношение к истории университета и опубликованные в литературе и периодических изданиях, как на русском, так и на иностранных языках, издававшихся как в России, так и за границей. Кроме того, в приложении публикуется и переписка профессоров университета, многие из которых адресованы конференц-секретарю Академии-наук Г.Ф. Миллеру. В т.3 (с.426-437) читатель найдет и еще одно приложение - список студентов Московского университета и дворянской и разночинской гимназий при университете за 1757 г. плод кропотливой работы составителя в архивах. Все документы публикуются на языке оригинала, а иностранные тексты - с переводом на русский.

Каждый том сопровождается предисловием, в котором сообщается о структуре издания, используемых архивах, рукописных фондах музеев и отделах рукописей библиотек. Во вступлении, на фоне истории университета охваченного периода, кратко описана тематика публикуемых документов. В предисловии к т. 1 излагается история изучения университета, и упоминается большинство ранее опубликованных документов. В конце тома читатель найдет примечания, список использованных печатных источников, словарь терминов, список сокращений и указатель имен.

Мы не имеем возможности детально анализировать все три тома, поэтому в этой рецензии мы покажем жанровое разнообразие опубликованных документов; кратко обрисуем основные темы, затронутые в них; обсудим принципы их отбора; на нескольких примерах покажем, что новое для историков первого в Росси

\footnotetext{
${ }^{3}$ Die Berliner und die Petersburger Akademie der Wissenschaften im Briefwechsel Leonard Eulers. Hrsg. Von A.P. Juškevič u. E. Winter unter Mitwirkung von P. Hoffmann und J.C. Kopelevič (Berlin, 1961), T. 2.
} 
национального университета дают опубликованные впервые документы; и остановимся на роли примечаний.

Часть опубликованных документов представляет собой определения, ордеры, доношения из государственных учреждений и деятелей, принимавших непосредственное участие в основании и развитии университета. К ним относятся Сенат, Московская сенатская контора, Штатс-контора и Московская штатс-контора, канцелярия Академии наук, Юстиц-коллегия, куратор Университета И.И. Шувалов, генерал-прокурор кн. Н.Ю. Трубецкой, сенатский архитектор кн. Д.В. Ухтомский, руководивший ремонтом и реконструкцией здания, а также и многочисленные университетские сотрудники, среди которых можно особо отметить директора А.М. Аргамакова, асессоров М.И. Веревкина, П.В. Хованского, М.М. Хераскова, а после кончины Аргамакова, нового директора И.И. Мелиссино, а также лиц принимавших участие организации университета, как в начальный период, так и в последующие годы: М.В. Ломоносов, Г.Ф. Миллер и их коллеги из иностранных университетов. Жанровое разнообразие опубликованных документов очень велико: тут и высочайшие и сенатские указы, доклады, рапорты университетской канцелярии и ордера куратора И.И. Шувалова, разнообразная переписка, публикации в журналах и газетах и т.д.

В 1754 г. речь идет об определении принципов, на которых будет основан университет, поиске подходящего здания для него, его ремонте и т.п. В 1755 г. документы повествуют об организации университета, о приведении к присяге куратора и директора, об уточнении штата университета и его гимназий, приглашении преподавателей и профессоров, наборе учащихся, инаугурации университета (26 апреля), взаимодействии с церковными властями, в том числе о публикации необходимых материалов в синодальной типографии, так как в начальный период своей у университета еще не было, наконец, устройстве собственной типографии, комплектовании библиотеки, в чем помощь университету оказала Академия наук, покупке нового здания для университета. Документы 1756 г. затрагивают вопросы финансирования и комплектования университета педагогическими кадрами, учреждения типографии и книжкой лавки, а также и издательства, продолжения комплектования библиотеки университета, ее открытия для преподавателей, студентов и учеников гимназии, а также для публики и т.д. Некоторые из этих вопросов отражены в 3 томе, относящемся к 1757 г. В т. 1 читатель найдет и интереснейшую (но использованную уже и до того) переписку по поводу церковной цензуры при подготовке в Московском университете перевода книги А. Попа Опыт о человеке.

Если мы посмотрим на список “частично использованных архивных документов,” опубликованный в т. 1 (т.е. список документов, не опубликованых в книге), то можно составить себе представление о принципах отбора. Большинство неопубликованных документов касается хозяйственных вопросов, однако, и среди опубликованных такого рода документов немало. Вероятно, составитель оценивал важность документа с точки зрения функционирования всего университета, в том числе ориентируясь на цифры (во многих неотобранных документах речь идет, например, о выделении сравнительно небольших сумм денег). Среди неотобранных документов иногда встречаются также и документы, касающиеся комплектования университета кадрами, но их смысловая нагрузка невелика (например, Л. Эйлер, на тот период профессор Берлинской Академии, предлагает И.Д. Шумахеру помощь в поиске преподавателей для университета, но, очевидно, сам текст никакой другой 
важной информации не содержит). В других случаях речь идет о документах, содержание которых повторяет отчасти те, что были опубликованы составителем (так, например, дело обстоит с серией документов, касающихся ряда учеников университета, в т.ч. В.И. Баженова, в т. 2). Нетрудно увидеть, что процент отобранных для публикации документов по сравнению с теми, которые составитель решил не публиковать, вырос в последующих томах, в особенности в т. 3:

\begin{tabular}{|c|c|}
\hline Год & \% найденных документов опубликованы \\
\hline 1754 & $51 \%$ \\
\hline 1755 & $73 \%$ \\
\hline 1756 & $71 \%$ \\
\hline 1757 & $86 \%$ \\
\hline
\end{tabular}

При этом мы не увидим в т. 3 больше мелких хозяйственных документов, чем в т. 1 и 2. Однако составитель принял решение включить в публикацию ряд документов, касающихся отдельных учеников Московского университета. Так, например, в т. 3, с. 122 находим “Аттестат Московского университета ученику гимназии И.П. Ральгину об учебе и поведении в связи с увольнением из университета" (6 мая 1757 г.) и тут же “Определение Сената об отсылке бывшего ученика Московского университета Н.И. Поливанова в лейб-гвардии Преображенский полк для определения в солдаты” (14 мая 1757 г.). Возможно, кто-то посчитает спорным включение в публикацию такого типа документов, касающихся судеб отдельных студентов, однако нам кажется, что в случае Московского университета, для которого, как известно, в первые годы его существования вопрос набора учеников стоял весьма остро, публикация документов, позволяющих проследить судьбы учеников, вполне оправдана. В подобных документах нередко содержится ценная информация, которая, как нам думается, представляет большой интерес для историка Московского университета. Например, из “Сказки бывшего ученика Московского университета В.М. Бирилева” (22 мая 1757 г.) мы узнаем о социальном уровне семьи и о родственном окружении ученика, в том числе о службе его родных; о том, сколько времени Бирилев на “казенном коште” учился в университете и чему; и почему он покидает университет (для определения в военную службу, которая для выходцев из дворян, а Бирилев был из дворянской семьи, представляла главную профессиональную стезю). В отдельных случаях по названию трудно понять, почему составитель отобрал документ для публикации, но обращение к документу часто проясняет причину. Так “Ордер куратора Московского университета И.И. Шувалова директору И.И. Мелиссино о контракте с обержистом" (т.е. содержателем гостиницы) (9 июня 1757 г.) содержит слова, интересные с точки зрения контроля за поведением учеников и персонала университета: "что бы у нево картошной игры никогда не было, от чего сколь от Университетских, сколь от посторонних, великие неудобности быть могут” (т. 3, с. 143). В то же время, нельзя не задуматься над тем, как такая редакторская политика широкого отбора документов для публикации отразится на будущих томах этой серии, которые, вероятно, не смогут уместиться под одной обложкой.

Документы, опубликованные в первых томах этой серии, дадут историку огромный массив информации по целому ряду вопросов, связанных с функционированием университета как сложного государственного, административно-хозяйственного, социального и педагогического организма. Мы найдем, например, значительный объем документов, касающихся набора профессоров в Московский университет, что позволит лучше понять механизм 
поиска и приглашения преподавателей. Хорошо известно, что значительное число первых преподавателей Московского университета были иностранцами, неудивительно, что опубликованные Д.Н. Костышиным документы дают много информации о работе этих иностранных специалистов в России, причем зачастую не только в рамках университета. Для историка изучения иностранных языков в России эта коллекция документов также будет иметь большое значение, поскольку многие документы посвящены вопросу организации обучения иностранных языков в университете. Мы уже упомянули и о многочисленных документах, касающихся набора студентов для университета и его гимназий, их учебе и их дальнейшей судьбе. Документы, опубликованные в приложениях, позволяют лучше увидеть, какой отклик открытие университета и его деятельность вызывали в русском обществе - на страницах прессы, во время торжественных собраний, публичных лекций и т.д. Другими словами, историк университета, да и историк российского общества второй половины XVIII в. вообще без сомнения найдет много интересных и полезных для себя документов в этих томах.

Необходимо также сказать несколько слов о примечаниях. Они содержат не только ссылки на литературу, но и биографические справки по упоминаемым в этой истории персонажам. В отдельных случаях мы имеем дело с весьма короткими справками. Так, например, в т. 1, прим. 2 посвящено главному лицу в истории Московского университета XVIII в. - И.И. Шувалову, однако весь текст его биографии умещается на менее чем одной странице. В т. 3, прим. 193 посвящено профессору медицины Московского университета Иоганну Христиану Керштенсу. Эта статья, однако, занимает 9,5 страниц! Очевидно, что составитель решил по возможности сократить примечания по лицам хорошо известным, о которых существует обширная и легко доступная литература, и дать максимально полные справки по персонажам менее известным. Эти биографические справки достойны пристального внимания, так как представляют собой зачастую результат долгих и детальных исследований, с опорой как на опубликованные, так и на неопубликованные источники. Так, упомянутая справка по Керштенсу основана на десятках источников, в том числе неопубликованных документах из четырех архивохранилищ. Поэтому, хотя эти примечания и не преследуют цели составить новый биографический словарь деятелей Московского университета, де факто они предлагают читателю во многих случаях наиболее полные на сегодня биографические справки деятелей Университета.

Появление этих трех томов уже без сомнения можно назвать важным событием не только в изучении истории Московского университета, но и в изучении русской культуры XVIII века вообще. В завершение этого краткого обзора позволим себе однако несколько замечаний, не относящихся напрямую к содержанию этих томов. Насколько нам известно, это издание (как и вся исследовательская деятельность, результатом которой стали эти книги) осуществляется исключительно на средства самого составителя. Учитывая высокое качество этих публикаций, открывающих новую страницу в истории университета, логичным нам кажется вопрос: почему руководство Московского университета до сих пор не поддержало финансово это издание? Если возможности Д.Н. Костышина позволяют ему выпускать подобные книги, это не значит, что ему не надо помогать. Кстати, тираж издания весьма скромный (в книге указана цифра в 500 экз., и хотелось бы верить, что она соответствует действительности), а возможности для распространения, которые предлагает издательство Academia, как нам кажется, 
более чем ограничены. Все наши попытки найти Историю Московского университета Д.Н. Костышина на сайте издательства не увенчались успехом. Эти книги не поступают и в розничную торговлю. Неудивительно, что их до сих пор невозможно обнаружить в главных европейских библиотеках. ${ }^{4}$ Поэтому надеемся, что это прекрасное начинание получит в будущем поддержку от главного российского университета, чью историю воссоздает Д.Н. Костышин.

4 Мы основываемся на данных сводного каталога Karlsruher Virtueller Katalog. Из крупных европейских библиотек, кажется, только в Британской библиотеке и библиотеке Оксфордского университета имеются некоторые из томов этой серии. Некоторые из этих книг можно найти и в американских библиотеках, однако число их все-таки очень незначительно. 